\title{
Studies of adjuvant-induced arthritis in the albino rat (CFN strain)
}

\author{
E. C. HENSON AND J. G. BRUNSON \\ Department of Pathology, University of Mississippi Medical Center, Jackson, Mississippi 39216
}

The need for more effective, but less toxic, drugs for treatment of diseases of the connective tissue in man is obvious. There is evidence which indicates that arthritis and certain other connective tissue diseases are caused by hypersensitive mechanisms (Pearson, 1959). Adjuvant-induced arthritis has been widely used as an experimental model of such diseases. The severity of the experimental disease has been decreased by use of the drugs (or agents); hydrocortisone and whole body irradiation (Pearson and Wood, 1959); other steroids, salicylates, and phenylbutazone (Newbould, 1963); 6-mercaptopurine (Kalliomäki, Saarimaa, and Toivanen, 1964); antilymphocyte sera (Currey and Ziff, 1966); statolon (Kapusta and Mendelson, 1967); lymphocyte depletion (Whitehouse and Whitehouse, 1968); and rubidomycin (Quagliata, Sanders, and Gardner, 1969). Many of the above drugs and agents are known to possess undesirable toxic effects at the dose levels necessary for suppressing inflammation and the immune response (Berenbaum, 1965).

Previous studies showed a combination of propiomazine (a phenothiazine derivative, Largon: Wyeth) and epinephrine to be effective in inhibiting the formation of circulating antibody and the Arthus reaction (Henson and Brunson, 1969a, Henson, Evers, and Brunson, 1970; Henson, Hartness, and Brunson, 1969). Additional studies showed the drug combination effective in inhibiting development of experimental allergic encephalomyelitis (EAE) in rabbits (Henson and Brunson, 1969b). The drug combination was effective without producing the severe toxic effects produced by many of the immunosuppressive drugs currently in clinical use. The present report concerns the effects of the combination of propiomazine and epinephrine on the development of adjuvantinduced arthritis in rats.

\section{Material and methods}

Eighty male albino rats (CFN strain) were caged in groups of three or less. They were fed a standard pellet ration and water ad libitum.

The rats were divided into a pre-treatment group (40 animals) and a group treated from the day of inoculation with adjuvant (40 animals). The forty rats of the pre-treatment group were further divided and treated as follows:

Group A (controls), ten animals given $0.5 \mathrm{ml}$. saline only;

GroUP B, ten animals given propiomazine only (Wyeth Laboratories) $(20 \mathrm{mg}$./kg. body wt);

Grou P C, ten animals given epinephrine only $(0.5 \mathrm{mg}$./ kg. body wt);

GROUP D, ten animals given a combination of propiomazine and epinephrine at the above concentrations.

The above concentrations of drugs were shown sufficient in unpublished pilot experiments. In the above pre-treatment groups the drugs were administered by a daily subcutaneous injection from 14 days before inoculation with adjuvant until completion of the experiment.

The forty animals of the group treated from the day of inoculation with adjuvant were also divided into four groups of ten each and treated as above until completion of the experiment.

The inoculation of the adjuvant was performed by modification of methods previously described (Flax and Waksman, 1963; Gery and Waksman, 1967). In the present studies a pad of each hind foot was injected with $0.1 \mathrm{ml}$. incomplete Freund's adjuvant (Difco Laboratories) emulsified with $0.3 \mathrm{mg}$. heat-killed $M$. tuberculosis bacilli (Difco Laboratories). The animals were observed daily from the date of administration of adjuvant. The disease was graded clinically on a $\mathbf{0}$ to 5 scale as follows:

0 , no reaction;

1, one joint involved;

2 , two joints involved;

3, more than two joints involved but mild inflammation;

4, more than two joints involved with marked polyarthritis and ankylosis;

5, very severe widespread polyarthritis with ankylosis. 


\section{Results}

The results of studies of arthritis production in the pre-treatment group are shown in Table I. Control animals showed severe lesions consisting of polyarthritis and ankylosis (Fig. 1). Animals treated with propiomazine only also showed marked polyarthritis (Fig. 2). The rats treated with epinephrine only showed less severe lesions (Fig. 3) than controls and those given propiomazine only. Animals in the group treated with the combination of propiomazine and epinephrine showed profound inhibition of development of arthritis (Fig. 4).

The results of studies with the group treated from the day of inoculation with the adjuvant are shown in Table II. Control animals and those given propiomazine only again showed development of severe polyarthritis. There was a high mortality rate in the group given epinephrine alone with only five of the original ten surviving at the completion of the experiment. The surviving animals of the latter group showed more severe arthritis than the group pre-treated with epinephrine. In the group given the combination of propiomazine and epinephrine, only two animals developed severe polyarthritis. One animal in this group died a few hours after the first injection from internal haemorrhage which resulted from rupture of an artery at time of injection. Seven of the animals in this group showed mild to absent lesion formation.

\section{Discussion}

Results of the present studies showed a combination of propiomazine and epinephrine to be effective in suppressing development of adjuvant-induced

Table I Effects of pre-treatment with a combination of propiomazine and epinephrine and each drug alone on the development of adjuvant arthritis in rats*

Severity of arthritis 25 days after administration of adjuvant $\dagger$

\begin{tabular}{|c|c|c|c|c|}
\hline \multirow[b]{2}{*}{ Animal No. } & \multirow[b]{2}{*}{ Controls } & \multicolumn{3}{|l|}{ Pre-treatment } \\
\hline & & Propiomazine only & Epinephrine only & Propiomazine and epinephrine \\
\hline $\begin{array}{r}1 \\
2 \\
3 \\
4 \\
5 \\
6 \\
7 \\
8 \\
9 \\
10\end{array}$ & $\begin{array}{l}3 \\
4 \\
4 \\
3 \\
4 \\
4 \\
4 \\
4 \\
3 \\
2\end{array}$ & $\begin{array}{l}1 \\
4 \\
4 \\
3 \\
3 \\
4 \\
2 \\
4 \\
3 \\
4\end{array}$ & $\begin{array}{l}5 \\
4 \\
2 \\
2 \\
3 \\
1 \\
0 \\
4 \\
-\end{array}$ & $\begin{array}{l}0 \\
1 \\
0 \\
1 \\
0 \\
2 \\
2 \\
0 \\
0 \\
0\end{array}$ \\
\hline
\end{tabular}

Rats pre-treated daily for 2 weeks before administration of adjuvant and until completion of experiment † System for grading severity of arthritis given in text

Table II Effects of a combination of propiomazine and epinephrine and each drug alone on the development of arthritis in rats*

Severity of arthritis 25 days after administration of adjuvant

\begin{tabular}{|c|c|c|c|c|}
\hline Animal No. & Controls & Propiomazine only & Epinephrine only & Propiomazine and epinephrine \\
\hline $\begin{array}{r}1 \\
2 \\
3 \\
4 \\
5 \\
6 \\
7 \\
8 \\
9 \\
10\end{array}$ & $\begin{array}{l}4 \\
1 \\
4 \\
5 \\
5 \\
4 \\
3 \\
5 \\
4 \\
5\end{array}$ & $\begin{array}{l}3 \\
4 \\
4 \\
5 \\
4 \\
4 \\
2 \\
3 \\
3 \\
3\end{array}$ & $\begin{array}{l}2 \\
3 \\
1 \\
1 \\
3 \\
= \\
= \\
=\end{array}$ & $\begin{array}{l}3 \\
0 \\
0 \\
0 \\
1 \\
5 \\
3 \\
0 \\
4 \\
\end{array}$ \\
\hline
\end{tabular}

* Rats treated daily from date of administration of adjuvant until completion of experiment tSystem for grading severity of arthritis given in text 
arthritis. The combination was effective when given before or after the day of inoculation with adjuvant. Although either drug when used alone was much less effective than the combination, epinephrine alone was more effective than propiomazine alone. Epinephrine alone was shown in earlier studies to increase the severity of the Arthus reaction in rabbits, rats, and mice (Henson and others, 1970; Henson and others, 1969) and also to increase the severity of local and generalized Shwartzman reactions in rabbits (Thomas, 1956; Barksdale, Henson, and Brunson, 1970). However, other workers found that epinephrine alone decreased the severity of inflammation resulting from simple forms of injury such as minor thermal injury and minor lacerations of skin (Spector and Willoughby, 1960). It was concluded in an earlier report that epinephrine acts to enhance inflammation when altered coagulation mechanisms are present (e.g. the Arthus and Shwartzman reactions) and decreases inflammation resulting from simple forms of injury (Henson and others, 1969).

Propiomazine and other phenothiazine derivatives have been shown to possess properties which

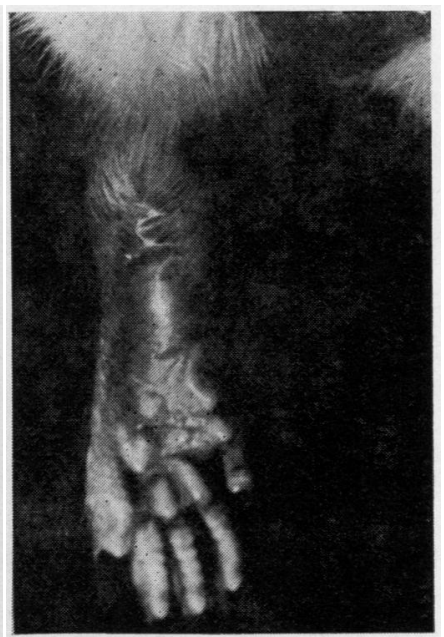

(2)

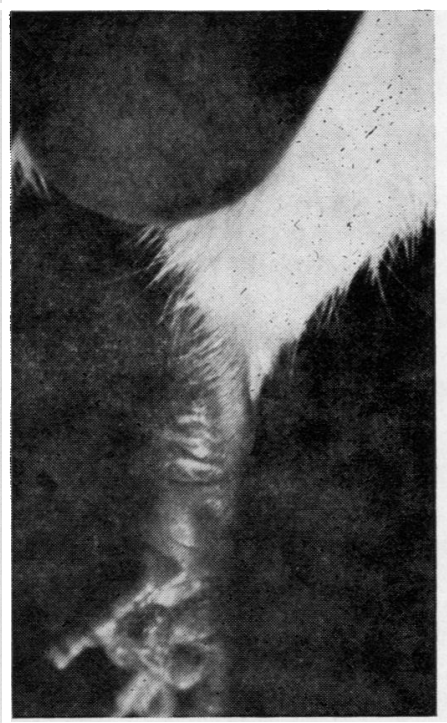

(4)

FIG. 2 Foot of propiomazine-treated rat 25 days after administration of adjuvant. Swelling of foot, toes, and joints is similar to that in Fig. 1.

FIG. 4 Foot of rat treated with the propiomazineepinephrine combination. Note apparent absence of arthritis. 
protect cells from noxious stimuli (Brunaud, Segal, Navarro, and Aurousseau, 1959; Fox, Dinman, and Frajola, 1962; Judah, 1962a). These drugs are reported to act by increasing the stability of cellular and subcellular systems (Judah, 1962b; Spirtes and Guth, 1961; Bangham, Rees, and Shotlander, 1962). Epinephrine is thought by the present authors to enhance the anti-inflammatory activity of propiomazine by acting on cells to make them more susceptible to the actions of the latter phenothiazine derivative. This is thought to result in treated animals being made refractory to stimuli which would otherwise be injurious to them. Epinephrine has been reported by other workers to enhance the activity of cortisone (Thorn, Jenkins, and Laidlaw, 1953; Tyler, 1953). The latter investigators suggested that epinephrine acted on leucocytes and made them more sensitive to the actions of cortisone. Their findings may support the concept that epinephrine enhances the activity of propiomazine.

It was pointed out in the introduction that many of the drugs used clinically for the treatment of arthritis cause severe undesirable side-effects. Previous studies have shown that the drug combination used in the present study does not deplete animals of lymphoid tissues or circulating leucocytes (Henson and Brunson, 1969a; Henson and others, 1969). The latter studies also showed that the drug combination decreased serum gamma globulin but increased alpha globulin levels, with the result that total serum protein levels remain similar to those of control animals. The authors feel that drug combinations similar to that used in the present study may offer an alternative approach to the problem of controlling the severity of arthritis. Future investigations will be concerned with more detailed studies involving suppression of the arthritic process by utilizing other combinations of phenothiazines and catecholamines and in determining the exact mechanisms of action of such drug mixtures.

\section{Summary}

Eighty male albino rats (CFN strain) were divided into one group of forty animals for pre-treatment with drugs (from 14 days before the administration of adjuvant) and another group of forty animals for treatment from the day of adjuvant administration. The groups were further divided into a control group and those treated with propiomazine (a phenothiazine derivative) only, epinephrine only, or a combination of propiomazine and epinephrine.

Animals in the pre-treatment group showed the following results: control animals produced severe polyarthritis; animals given propiomazine only also produced severe arthritis; those given epinephrine only produced obvious arthritis but of a less severe nature than controls and those given propiomazine only; those given the mixture of propiomazine and epinephrine showed profound inhibition of arthritis development.

Animals treated from the day of administration of adjuvant showed similar results, but there was a slight increase in the severity of arthritis in those which received the drug combination.

These data may suggest an alternative approach to suppression of the arthritic process.

\section{References}

Bangham, A. D., Rees, K. R., and Shotlander, V. (1962) Nature (Lond.), 193, 754 (Penetration of lipid films by compounds preventing liver necrosis in rats).

Barksdale, B., Henson, E. C., ANd Brunson, J. G. (1970) A.M.A. Arch. Path. In press (Effects of epinephrine on generalize 1 Shwartzman).

Berenbaum, M. C. (1965) Brit. med. Bull., 21, 140 (Immunosuppressive agents).

Brunaud, M., Segal, V., Navarro, J., and Aurousseau, M. (1959) Arch. int. Pharmacodyn., 119, 367 (Recherches sur les propriétés pharmacodynamiques comparées de la propiomazine (1678CB) et de la prométhazine).

CURREY, H. L. F. AND ZIFF, M. (1966) Lancet, 2, 889 (Suppression of experimentally-induced polyarthritis in the rat by heterologous anti-lymphocyte serum).

Flax, M. H. and Waksman, B. H. (1963) Int. Arch. Allergy, 23, 331 (Further immunologic studies of adjuvant disease in the rat).

Fox, C. F., Dinman, B. D., And Frajola, W. J. (1962) Proc. Soc. exp. Biol. (N. Y.), 111, 731 (CCl 4 poisoning. II. Serum enzymes, free fatty acids and liver pathology; effects of phenoxybenzamine and Phenergan).

Gery, I. AND WaKsman, B. H. (1967) Int. Arch. Allergy, 31, 57 (Studies of the mechanism whereby adjuvant disease is suppressed in rats pretreated with mycobacteria).

Henson, E. C. AND Brunson, J. G. (1969a) Nature (Lond.), 222, 593 (Inhibition of circulating antibody formation induced by propiomazine and epinephrine combination).

(1969b) Proc. Soc. exp. Biol. (N.Y.), 131, 752 (Prevention of experimental allergic encephalomyelitis by combination of epinephrine and a phenothiazine derivative, propiomazine).

-, Evers, C. G., ANd Brunson, J. G. (1970) Int. Arch. Allergy. 34, 458 (Prevention of the Arthus reaction in rats and mice by combination of epinephrine and a phenothiazine derivative propiomazine).

- - Hartness, S., AND Brunson, J. G. (1969) A.M.A. Arch. Path., 88, 249 (Adrenal medullary hormones and phenothiazine. Effects on the Arthus reaction in adult rabbits). 
JudAH, J. D. (1962a) 'Protection against cellular injury by drugs' in 'Ciba Foundation Symposium: Enzymes and Drug Action', ed. J. L. Mongar and A. V. S. de Reuck, p. 359. Churchill, London.

- (1962b) Fed. Proc., 21, 1097 (Action of antihistamine and other drugs on ion and water movements in cells and mitochondria).

Kalliomäki, J. L., SaArimaA, H. A., And Toivanen, P. (1964) Ann. rheum. Dis., 23, 78 (Inhibition by 6-mercaptopurine of polyarthritis induced by Freund's adjuvant).

Kapusta, M. A. AND Mendelson, J. (1967) Proc. Soc. exp. Biol. (N.Y.), 126, 496 (Inhibition of adjuvant arthritis by statolon).

Newbould, B. B. (1963) Brit. J. Pharmacol., 21, 127 (Chemotherapy of arthritis induced in rats by mycobacterial adjuvant).

Pearson, C. M. (1959) 'Development of arthritis in the rat following injection with adjuvant', in 'Henry Ford Hospital International Symposium: Mechanisms of Hypersensitivity', ed. J. H. Shaffer, G. A. LoGrippo, and M. W. Chase, p. 647. Little, Brown, Boston.

- AND WooD, F. D. (1959) Arthr. and Rheum., 2, 440 (Studies of polyarthritis and other lesions induced in rats by injection of mycobacterial adjuvant. I. General clinical and pathological characteristics and some modifying factors).

Quagliata, F., Sanders, P. M., And Gardner, D. L. (1969) Ann. rheum. Dis., 28, 163 (Suppression of adjuvant arthritis by a new cytotoxic compound, rubidomycin).

Spector, W. G. AND Willoughby, D. A. (1960) J. Path. Bact., 80, 271 (The enzymic inactivation of an adrenalin-like substance in inflammation).

SPIRTES, M. A. AND GUTH, P. S. (1961) Nature (Lond.), 190, 274 (An effect of chlorpromazine on rat mitochondrial membranes).

Thomas, L. (1956) J. exp. Med., 104, 865 (The role of epinephrine in the reactions produced by the endotoxins of Gram negative bacteria. I. Hemorrhagic necrosis produced by epinephrine in the skin of endotoxin tested rabbits).

Thorn, G. W., Jenkins, D., and Laidlaw, J. C. (1953) Rec. Progr. Hormone Res., 8, 171 (The adrenal response to stress in man).

TYler, F. H. (1953) Ibid., 8, 268 (Discussion on connective tissue and the adaptation concept).

Waksman, B. H., Pearson, C. M., AND Sharp, J. T. (1960) J. Immunol., 85, 403 (Studies on arthritis and other lesions induced in rats by injection of mycobacterial adjuvant. II. Evidence that the disease is a disseminated immunologic response to exogenous antigen).

Whitehouse, M. W. AND Whitehouse, D. J. (1968) 'Programme of Annual Meeting of Amer. Rheum. Ass., 1968' (Abst. 58: Inhibition of rat adjuvant arthritis without drugs or antibody therapy).

\section{RÉSUMÉ}

Etudes de l'arthrite causée par un adjuvant chez les rats albinos (souche CFN)

80 rats albinos (souche CFN) ont été divisés en un groupe de 40 animaux pour être traités avec des médicaments 14 jours avant l'administration de l'adjuvant et un autre groupe de $\mathbf{4 0}$ animaux pour être traités depuis le jour de l'administration de l'adjuvant. Ces deux groupes ont de plus encore été divisées en un groupe de témoins, et d'autres groupes traitées à la propiomazine (un dérivé de phenothiazine) seulement, à l'épinéphrine seulement ou à une combinaison de propiomazine et d'épinéphrine.

Les animaux du groupe traités 14 jours avant l'administration de l'adjuvant ont donné les résultats suivants: Les animaux témoins ont eu une polyarthrite grave; les animaux qui avaient reçu la propiomazine seulement ont aussi eu une polyarthrite grave; ceux qui avaient reçu l'épinéphrine seulement ont eu une arthrite évidente mais d'une gravité moins marquée celle des témoins et que celle du groupe qui avait reçu de la propiomazine seulement; le groupe traité avec une combinaison de propiomazine et d'épinéphrine a montré une inhibition marquée au développement arthritique.

Les animaux traités à partir du jour de l'administration de l'adjuvant ont donné des résultats semblables, mais il $y$ avait une légère augmentation dans la gravité de l'arthrite chez ceux qui avaient reçu des médicaments combinés. Ces données peuvent suggérer un procédé altérnatif pour la suppression du processus arthritique.

\section{SUMARIO}

Estudios de la artritis inducida por adyuvante en la rata albina (especie CFN)

80 ratas albinas machos (especie CFN) fueron divididas en dos grupos: uno, de $\mathbf{4 0}$ animales para pretratamiento con drogas (14 días antes de la administración de adyuvante), y otro grupo de $\mathbf{4 0}$ animales para tratamiento desde el día de la administración de adyuvante. Los grupos fueron, además, divididos en un grupo testigo y aquellos tratados con propiomacina (un derivado de la fenotiacina) solamente, con epinefrina solamente, o una combinación de propiomacina y epinefrina.

Los animales del grupo de pretratamiento revelaron los siguientes resultados: los animales testigo desarrollaron poliartritis severa; los animales que recibieron propiomacina solamente desarrollaron, también, artritis severa; aquellos que recibieron epinefrina solamente desarrollaron artritis evidente, pero de naturaleza menos severa que la de los testigos y que aquellos que recibieron propiomacina solamente; los animales que recibieron la mezcla de propiomacina y epinefrina mostraron profunda inhibición del desarrollo artrítico.

Los animales tratados a partir del día de la administración de adyuvante revelaron resultados similares, pero se observó un ligero aumento en la severidad de la artritis en aquellos que recibieron las drogas combinadas.

Estos datos quizá sugieran que debe abordarse de otro modo la supresión del proceso artrítico. 